\title{
Livestock farmers perceptions on the relevance of natural licks in Igambang'ombe Division, Tharaka-Nithi County, Kenya
}

\author{
Onesmus Munene Nderi ${ }^{1, *}$, Levi Mugalavai Musalia ${ }^{1}$, Ochieng Ombaka ${ }^{2}$ \\ ${ }^{I}$ (Department of Animal Sciences, Chuka University, Kenya) \\ ${ }^{2}$ (Department of Physcal sciences, Chuka University, Kenya)
}

\begin{abstract}
A survey covering 12 Sublocations in Igambang'ombe Divsion and involving 72 respondents was conducted to ascertain perceptions on the relevance of natural licks. Household survey, focus group discussions and direct observations were employed. A structured questionnaire which had been subjected to face validity with a reliability coefficient of 0.84 was used to collect data, and analysed using SPSS for percentages, standard deviation and ANOVA. The relationship betweeen demographic characteristics of farmers and their perceptions on the relevance of natural licks was explored. Majority of livestock farmers were male (61.1\%), aged 21 to 40 years (41.7\%), had Primary education (52.8\%), monthly income below Kenya shillings 5000 (75\%), earned income from mixed farming (88.9\%) and had farming experience of $\geq 10$ years $(72.2 \%)$. Farmers preferred animals licking at the natural sites (62.5\%), and obtained information through traditional practices (87.5\%). Natural licks are available (63.9\%) and are perceived to improve digestion (77.8\%), increase milk production (56.9\%), provide minerals (81.9\%) and medicinal value (48.6\%) to the animals. The licks are sold (63.9\%) at Kenya shillings 40 per 2 Kilograms(40.1\%). There was no statistically significant difference in perceptions between men and women, educated and uneducated farmers. Farmers believed that natural licks are relevant.

Keywords: Demographic characteristics, Livestock farmers, Natural licks, Perception, Relevance.
\end{abstract}

\section{Introduction}

According to the Council of European Union report, about 870 million people in the world are suffering from hunger [1]. The report stresses on the need to increase and diversify Agriculture mainly in the food insecure Countries in order to reduce the problem of hunger. In the past, most developing countries regarded agriculture to be a low returns and traditional sector that only produced food and employment[2]. It is however documented that agriculture contributes significantly to economic growth and promotes living standards in many rural areas of Africa[3]. Agriculture forms the backbone of Kenya's economy, and it is a major driver of the proposed 10\% economic growth per annum envisioned in the Kenya's Vision 2030[4].

Livestock production which is a subsector in Agriculture, plays a major economic and social activity in Kenya, accounting for about $10 \%$ and $42 \%$ of entire Gross Domestic Product and Agricultural Domestic Product respectively[5]. Most Kenyan communities have traditionally reared animals for subsistence, prestige, and insurance against draught, but currently they are adopting livestock production as a foreign exchange earner through export of live animals, animal products and their by-products[6]. However, animal nutrition is a major production challenge in many smallholder production systems[7]. One of the challenges facing many smallholder livestock producers is inability to satisfy mineral requirement of their animals leading to reduced productivity[8]

More than 50 species of animals in the world have been reported to ingest various types of earth materials in the natural licks[9]. The reasons for consuming the licks are not clearly understood, but animals are argued to obtain both nutritional and health benefits[10]. Some perceived benefits from natural licks to the animals are; sources of minerals and to alleviate the effects of digestive disorders and toxic plant secondary metabolites[11]. The existence of natural licks in an area may reduce the costs of obtaining sufficient nutrition, and would play a role in maintaining healthy animals. This might be important in tropical countries like Kenya where mineral deficiencies and imbalances are common and have significant effects on health and productivity of livestock.

Traditionally, livestock producers in Igambang,ombe, have relied on natural licks as sources of minerals for their animals. The animals kept by these producers scavenge for minerals by consuming soils from specific sites on the ground known as natural licks (Mwonyo). Though the soil (natural lick) is seemingly well known by the rural communities, no study on perceived benefits has been conducted on it. Further, indigenous knowledge about the use of natural licks as a natural resource for the animals has never been documented in the County. 
Livestock farmers perceptions on the relevance of natural licks in Igambang'ombe Division, ....

1.1 Objectives

The main objective of the study was to analyse the perceptions of livestock farmers on natural licks in Igambang'ombe Diviosn in Tharaka-Nithi County, Kenya. In order to meet this objective, the following specific objectives were formulated:-

a) To identify demographic characteristics of the farmers

b) To determine the level of perceptions of farmers on the relevance of natural licks

c) To ascertain the level of awareness on trade and benefits of natural licks

\subsection{Study area}

\section{Materials and methods}

Informal survey was conducted between June and November 2013 covering all the 12 administrative Sub locations in Igambang'ombe Division in Tharaka-Nithi County, Kenya. The aim was to collect information on the indigineous knowledge on natural licks and perception of livestock farmers on the availability, usage, benefits and trade of natural licks. The study area was chosen because of the presence of natural licks which were known to have historical use by livestock farmers.

The Division is situated between Latitude $0^{\circ} 19^{\prime} 60$ South and Longitude $37^{\circ} 38^{\prime} 60$ East in TharakaNithi County on the Eastern side of Mt. Kenya. The region has a bimodal rainfall distribution pattern with the long rains falling between March and May and the short rains between October and December. The average rainfall ranges between 200 and $800 \mathrm{~mm}$ per year. The ambient temperatures range between $22^{\circ} \mathrm{C}$ and $27^{\circ} \mathrm{C}$, with the lowest temperatures being in July and the highest in January. Geologically, the County can be separated into volcanic and basement systems. Volcanic soils are derived from volcanic parent material from Mt. Kenya, and they range from very deep red (nitisols and andosols), to moderately deep clay, and shallow soils with various textures on the mountain ridges and volcanic plateau respectively. The soils derived from the basement system rocks are usually moderately deep to shallow with loam to clay textures (cambisols luvisols and regosols), whereas those of the hills are very shallow and rocky (leptosols) [12].

\subsection{Sampling design}

Three complementary methods were employed in collection of primary data; Household survey, focus group discussions and direct observations. The household survey was conducted first using simple random sampling method in order to avoid any influence by other farmers who had taken part in group discussions. Purposive selection was done on farmers who had been in livestock farming for longer periods of time and had better knowledge of natural licks to participate in group discussion. These farmers were selected based on information provided by the village elders.

\section{Data collection and Analysis}

A total of 72 structured questionnaires were randomly administered to capture the socio-demographic, socio-economic and socio-cultural data. Notice of the visit was not given to avoid influence of the respondents. Data collected included gender, age, education, household size, monthly income, sources of income, farmers knowledge on natural licks, natural lick's availability, usage, perceived benefits and trade. The designing of the questionnaire was based on review of related literature and objectives of the study. The face validation was carried out using a similar sample group from Nairobi Ndogo village which was not sampled before. More information was obtained through direct observations by research assistants who participated in the household surveys and documented as field notes. Secondary data to augment the research included livestock production estimates and livestock production systems from the Ministry of Livestock Development and Kenya National Bureau of Statistics (KNBS).

All data was analysed using Statistical package for Social Sciences version 17 [13] for percentages, standard deviation and analysis of variance (ANOVA) test for significance of association between farmers demographic characterstics and their perceptions on the benefits of natural licks.

\section{Results And Dicussion}

\subsection{Socio-demographic characteristics of the respondents}

The distribution of respondents based on gender, age, education, Household size are summarised in Table 1 below. Out of the total number of respondents, $61.1 \%$ were male, and this indicates their dominance in farming activities which may be due to their access to farm land and their position as head of the family. The low proportion of female farmers could be due to their inability to own farmland and the fact that they preferred to engage in trade, casual labour and domestic chores. Secondly, this can be associated with the energetic nature of males compared to females, and also the risks involved in livestock farming like long distance travel and culural conflicts while searching for pastures and water. These results agrees with the work of Khan and Akram [14], who concluded that farming is a male dominated profession. 
Majority of the farmers (41.7\%) were aged between 21 to 40 years, $23.6 \%$ were in the age bracket of 41-50 years and 13.9\% were 51-60 years of age.This might indicate a high level of School dropouts after Primary education who turned to livestock farming and trade. About $12.5 \%$ of the respondents had no formal education while majority $(52.8 \%)$ had attained basic Primary education level, while $1.4 \%$ had A level qualification and $15.3 \%$ had College education. This high rate of school dropout leaves majority of residents with no other alternative but to engage in subsistence livestock farming because the area is Semi Arid, and inability of semi-illiterate farmers to embrace to new farming production methods like Agribusiness. This agrees with the report given by Garba and others [15]. Majority of the households (55.6\%) had four to six members which can be alluded to poverty in the region that leads to early School dropouts who eventually end up in early marriages.

Table 1: Distribution of the respondents according to gender age level of education and Household size $(n=72)$

\begin{tabular}{|c|c|c|c|c|c|c|c|c|c|c|c|c|c|}
\hline Sublocations & $\begin{array}{c}\text { Kam } \\
\text { won } \\
\text { ka } \\
(\%)\end{array}$ & $\begin{array}{c}\text { Kant } \\
\text { hanj } \\
\mathrm{e} \\
(\%)\end{array}$ & $\begin{array}{c}\mathrm{Mu} \\
\text { tin } \\
\mathrm{o} \\
(\%)\end{array}$ & $\begin{array}{c}\mathrm{Ka} \\
\mathrm{nju} \\
\mathrm{ki} \\
(\%)\end{array}$ & $\begin{array}{c}\text { Kam } \\
\text { utiria } \\
(\%)\end{array}$ & $\begin{array}{c}\text { Mak } \\
\text { anya } \\
\text { nga } \\
(\%)\end{array}$ & $\begin{array}{l}\text { Kamai } \\
\text { ndi } \\
(\%)\end{array}$ & $\begin{array}{l}\text { Igam } \\
\text { bang' } \\
\text { omb } \\
\mathrm{e} \\
(\%)\end{array}$ & $\begin{array}{c}\text { Kia } \\
\text { rith } \\
\text { a } \\
(\%)\end{array}$ & $\begin{array}{c}\text { Igama } \\
\text { tundu } \\
(\%)\end{array}$ & $\begin{array}{c}\text { Kamwi } \\
\text { mbi } \\
(\%)\end{array}$ & $\begin{array}{c}\text { Mbog } \\
\text { oni } \\
(\%)\end{array}$ & $\begin{array}{l}\text { Total } \\
(\%)\end{array}$ \\
\hline \multicolumn{14}{|l|}{ Gender } \\
\hline Male & 60.0 & 71.4 & $\begin{array}{r}66 . \\
7\end{array}$ & $\begin{array}{r}71 . \\
4\end{array}$ & 80.0 & 50.0 & 50.0 & 16.7 & $\begin{array}{r}66 . \\
7\end{array}$ & 85.7 & 66.7 & 40.0 & 61.1 \\
\hline Female & 40.0 & 28.6 & $\begin{array}{r}33 . \\
3\end{array}$ & $\begin{array}{r}28 . \\
6\end{array}$ & 20.0 & 50.0 & 50.0 & 83.3 & $\begin{array}{r}33 . \\
3\end{array}$ & 14.3 & 33.3 & 60.0 & 38.9 \\
\hline \multicolumn{14}{|l|}{ Age (Years) } \\
\hline$<20$ & .0 & .0 & $\begin{array}{r}16 . \\
7\end{array}$ & .0 & .0 & .0 & 16.7 & .0 & .0 & .0 & .0 & 20.0 & 4.2 \\
\hline $21-40$ & 40.0 & 57.1 & $\begin{array}{r}16 . \\
7\end{array}$ & $\begin{array}{r}42 . \\
9\end{array}$ & 40.0 & 33.3 & 33.3 & 66.7 & $\begin{array}{r}66 . \\
7\end{array}$ & 42.9 & 50.0 & .0 & 41.7 \\
\hline $41-50$ & 40.0 & 14.3 & $\begin{array}{r}33 . \\
3\end{array}$ & $\begin{array}{r}42 . \\
9\end{array}$ & .0 & 50.0 & 16.7 & 16.7 & $\begin{array}{r}33 . \\
3\end{array}$ & .0 & .0 & 40.0 & 23.6 \\
\hline $51-60$ & .0 & 14.3 & $\begin{array}{r}16 . \\
7\end{array}$ & $\begin{array}{r}14 . \\
3\end{array}$ & 40.0 & 16.7 & 33.3 & .0 & .0 & 14.3 & 16.7 & .0 & 13.9 \\
\hline$>60$ & 20.0 & 14.3 & $\begin{array}{r}16 . \\
7\end{array}$ & .0 & 20.0 & .0 & .0 & 16.7 & .0 & 42.9 & 33.3 & 40.0 & 16.7 \\
\hline \multicolumn{14}{|l|}{ Education } \\
\hline None & .0 & 14.3 & $\begin{array}{r}16 . \\
7\end{array}$ & $\begin{array}{r}28 . \\
6\end{array}$ & .0 & 16.7 & .0 & 16.7 & $\begin{array}{r}16 . \\
7\end{array}$ & 14.3 & 16.7 & .0 & 12.5 \\
\hline Primary & 60.0 & 57.1 & $\begin{array}{r}50 . \\
0\end{array}$ & $\begin{array}{r}28 . \\
6\end{array}$ & $\begin{array}{r}100 . \\
0\end{array}$ & 83.3 & 33.3 & 33.3 & $\begin{array}{r}50 . \\
0\end{array}$ & 57.1 & 50.0 & 40.0 & 52.8 \\
\hline Secondary & 40.0 & 28.6 & .0 & $\begin{array}{r}14 . \\
3\end{array}$ & .0 & .0 & 33.3 & .0 & .0 & 14.3 & 33.3 & 60.0 & 18.1 \\
\hline A level & .0 & .0 & .0 & .0 & .0 & .0 & .0 & .0 & $\begin{array}{r}16 . \\
7\end{array}$ & .0 & .0 & .0 & 1.4 \\
\hline College & .0 & .0 & $\begin{array}{r}33 . \\
3\end{array}$ & $\begin{array}{r}28 . \\
6\end{array}$ & .0 & .0 & 33.3 & 50.0 & $\begin{array}{r}16 . \\
7\end{array}$ & 14.3 & .0 & .0 & 15.3 \\
\hline \multicolumn{14}{|c|}{$\begin{array}{l}\text { House hold size } \\
\text { (persons) }\end{array}$} \\
\hline$<3$ & 40.0 & .0 & .0 & $\begin{array}{r}28 . \\
6\end{array}$ & 20.0 & 16.7 & 16.7 & 16.7 & .0 & 28.6 & .0 & .0 & 13.9 \\
\hline $4-6$ & 40.0 & 57.1 & $\begin{array}{r}83 . \\
3\end{array}$ & $\begin{array}{r}57 . \\
1\end{array}$ & 20.0 & 33.3 & 50.0 & 66.7 & $\begin{array}{r}83 . \\
3\end{array}$ & 42.9 & 66.7 & 60.0 & 55.6 \\
\hline $7-10$ & .0 & 28.6 & $\begin{array}{r}16 . \\
7\end{array}$ & .0 & 60.0 & 33.3 & 16.7 & 16.7 & $\begin{array}{r}16 . \\
7\end{array}$ & 14.3 & 33.3 & .0 & 19.4 \\
\hline$>10$ & 20.0 & .0 & .0 & .0 & .0 & 16.7 & .0 & .0 & .0 & 14.3 & .0 & .0 & 4.2 \\
\hline No response & .0 & 14.3 & .0 & $\begin{array}{r}14 . \\
3\end{array}$ & .0 & .0 & 16.7 & .0 & .0 & .0 & .0 & 40.0 & 6.9 \\
\hline
\end{tabular}

\subsection{Socio-economic characteristics of the respondents}

The data on monthly income, major source of income and duration of rearing livestock are summarized in Table 2 below. This study revealed that majority of farmers (75\%) earned below Kenya shillings 5000 per month. This is partly contributed by the fact that the study area is Semi Arid and the only major income earner is livestock farming which earns meager income. Further, crop farming is unreliable due to the low rainfall level in the region. The aspect of crop farming has been supported by the findings of this investigation in which majority of the respondents $(88.9 \%)$ practices mixed farming. This is in agreement with the findings of Central Bureau of Statistics (CBS) and International Livestock Research Institute (ILRI) [16] which recorded that poverty was more pronounced among livestock keepers in Kenya.

This trend can be reduced by development of cottage industries that would utilize natural resources like natural licks to make useful products that can earn income and improve rural livelihood. Many of the livestock 
farmers $(72.2 \%)$ had been in livestock farming for not less than 10 years which implies that, it is the main occupation in the study area.

Table 2: Distribution of respondents according to monthly income major source of income and duration of rearing livestock $(\mathrm{n}=72)$

\begin{tabular}{|c|c|c|c|c|c|c|c|c|c|c|c|c|c|}
\hline $\begin{array}{l}\text { Sublocati } \\
\text { ons }\end{array}$ & $\begin{array}{c}\text { Kam } \\
\text { wonk } \\
\text { a } \\
(\%)\end{array}$ & $\begin{array}{c}\text { Kant } \\
\text { hanj } \\
\mathrm{e} \\
(\%)\end{array}$ & $\begin{array}{c}\text { Muti } \\
\text { no } \\
(\%)\end{array}$ & $\begin{array}{c}\text { Kanj } \\
\text { uki } \\
(\%)\end{array}$ & $\begin{array}{c}\text { Kam } \\
\text { utiri } \\
\text { a } \\
(\%)\end{array}$ & $\begin{array}{c}\text { Mak } \\
\text { anya } \\
\text { nga } \\
(\%)\end{array}$ & $\begin{array}{c}\text { Kam } \\
\text { aindi } \\
(\%)\end{array}$ & $\begin{array}{c}\text { Igam } \\
\text { bang' } \\
\text { ombe } \\
(\%)\end{array}$ & $\begin{array}{c}\text { Kiari } \\
\text { tha } \\
(\%)\end{array}$ & $\begin{array}{l}\text { Iga } \\
\text { matu } \\
\text { ndu } \\
(\%)\end{array}$ & $\begin{array}{c}\text { Kamwi } \\
\text { mbi } \\
(\%)\end{array}$ & $\begin{array}{l}\text { Mbo } \\
\text { goni } \\
(\%)\end{array}$ & Total \\
\hline \multicolumn{14}{|c|}{$\begin{array}{l}\text { Monthly income } \\
\text { (Kenya Shillings) }\end{array}$} \\
\hline $\begin{array}{l}\text { Below } \\
5,000\end{array}$ & 60.0 & 71.4 & $\begin{array}{r}100 . \\
0\end{array}$ & 71.4 & 60.0 & 83.3 & 83.3 & 100.0 & 66.7 & 57.1 & 83.3 & 60.0 & 75.0 \\
\hline $\begin{array}{l}5,001- \\
10,000\end{array}$ & 20.0 & 14.3 & .0 & 14.3 & 20.0 & 16.7 & 16.7 & .0 & 16.7 & 14.3 & .0 & 20.0 & 12.5 \\
\hline $\begin{array}{l}10,001- \\
20,000\end{array}$ & .0 & 14.3 & .0 & .0 & .0 & .0 & .0 & .0 & .0 & 14.3 & .0 & .0 & 2.8 \\
\hline $\begin{array}{l}20,001- \\
50,000\end{array}$ & 20.0 & .0 & .0 & 14.3 & 20.0 & .0 & .0 & .0 & 16.7 & 14.3 & 16.7 & .0 & 8.3 \\
\hline $\begin{array}{l}\text { Above } \\
50,000\end{array}$ & .0 & .0 & .0 & .0 & .0 & .0 & .0 & .0 & .0 & .0 & .0 & 20.0 & 1.4 \\
\hline $\begin{array}{l}\text { Major sou } \\
\text { of income }\end{array}$ & & & & & & & & & & & & & \\
\hline $\begin{array}{l}\text { Livestock } \\
\text { keeping }\end{array}$ & .0 & 1.4 & 1.4 & .0 & .0 & 1.4 & .0 & 1.4 & .0 & 1.4 & .0 & .0 & 6.9 \\
\hline $\begin{array}{l}\text { Crop } \\
\text { farming }\end{array}$ & .0 & 1.4 & .0 & .0 & .0 & 1.4 & .0 & .0 & .0 & .0 & .0 & .0 & 2.8 \\
\hline $\begin{array}{l}\text { Mixed } \\
\text { farming }\end{array}$ & 6.9 & 6.9 & 6.9 & 9.7 & 6.9 & 5.6 & 8.3 & 6.9 & 8.3 & 8.3 & 6.9 & 6.9 & 88.9 \\
\hline None & .0 & .0 & .0 & .0 & .0 & .0 & .0 & .0 & .0 & .0 & 1.4 & .0 & 1.4 \\
\hline \multicolumn{14}{|c|}{$\begin{array}{l}\text { Duration of rearing } \\
\text { Livestock (years) }\end{array}$} \\
\hline $\begin{array}{l}5 \text { and } \\
\text { below }\end{array}$ & 1.4 & 1.4 & 1.4 & 1.4 & .0 & .0 & 4.2 & 1.4 & .0 & .0 & 1.4 & 1.4 & 13.9 \\
\hline $6-10$ & 1.4 & 1.4 & 1.4 & 1.4 & 1.4 & 1.4 & 1.4 & 1.4 & .0 & .0 & 1.4 & 1.4 & 13.9 \\
\hline $\begin{array}{l}10 \text { and } \\
\text { above }\end{array}$ & 4.2 & 6.9 & 5.6 & 6.9 & 5.6 & 6.9 & 2.8 & 5.6 & 8.3 & 9.7 & 5.6 & 4.2 & 72.2 \\
\hline
\end{tabular}

\subsection{Socio-cultural characteristics}

The study also sought to establish the extent to which the respondents agreed or disagreed with each of the following statements relating to the source of minerals for the animals in the area and how farmers acquired knowledge of the natural licks.. The responses were rated on a five point Likert scale, where: 1- strongly disagree, 2- disagree, 3- neither disagrees nor agrees, 4- Agree and 5- Strongly agree. The percentages and standard deviations were generated from SPSS and are as illustrated in Table 3. below.

From the study findings, majority of the respondents (62.5\%) strongly agreed that farmers preferred animals licking naturally occurring minerals at the sites (Table 3) as demonstrated in Fig. 1. This is due to availability and free access of natural licks in the region, and poverty level that makes the locals unable to purchase the commercial mineral licks.

Different sources of information on natural licks by farmers was explored in the present investigation. Results in Table 3 shows that $(87.5 \%)$ of the respondents strongly agreed that, they obtain information on natural licks through traditional practices. This implies that traditional knowledge was the main source of knowledge on natural licks among the farmers in Igambangombe. The main reason is that, the knowledge on natural licks has not been explored and documented, thus it is not in public domain for dissemination with other media.

A close examination of Table 3 reveals that, the standard deviation ranges between 0.484 to 1.625 . This range indicates that, farmers perceptions towards sources of minerals and sources of information on natural licks does not vary to a great extent. Thus the farmer's responses were consistent to some extent. 
Livestock farmers perceptions on the relevance of natural licks in Igambang'ombe Division, ....

Table 3: Source of minerals for the animals and information on natural licks $(n=72)$

\begin{tabular}{lllllll}
\hline Variables & $\begin{array}{l}\text { Strongly } \\
\text { disagree } \\
(\%)\end{array}$ & $\begin{array}{l}\text { Disagree } \\
(\%)\end{array}$ & $\begin{array}{l}\text { Neutral } \\
(\%)\end{array}$ & Agree $(\%)$ & $\begin{array}{l}\text { Strongly agree } \\
(\%)\end{array}$ & $\begin{array}{l}\text { Standard } \\
\text { deviation }\end{array}$ \\
\hline $\begin{array}{l}\text { Sources of minerals } \\
\text { Farmers buy Commercial licks } \\
\text { from agro dealers }\end{array}$ & 30.6 & 18.1 & 18.1 & 5.6 & 27.8 & 1.604 \\
$\begin{array}{l}\text { Farmers prefer animals licking } \\
\text { naturally occurring minerals }\end{array}$ & 13.9 & 12.5 & 2.8 & 8.3 & 62.5 & 1.559 \\
$\begin{array}{l}\text { Collect natural licks and take to } \\
\text { animals }\end{array}$ & 33.3 & 18.1 & 18.1 & 18.1 & 12.5 & 1.432 \\
$\begin{array}{l}\text { Buying natural licks for the } \\
\text { animals }\end{array}$ & 47.2 & 13.9 & 9.7 & 8.3 & 20.8 & 1.625 \\
$\begin{array}{l}\text { Don't use commercial or } \\
\text { natural licks }\end{array}$ & 75.0 & 11.1 & 5.6 & 2.8 & 5.6 & 1.100 \\
Sources of information & & & & & & \\
Reading literature & 87.5 & 6.9 & 0.0 & 1.4 & 4.2 & .892 \\
$\begin{array}{l}\text { Electronic media like radios and } \\
\text { TV }\end{array}$ & 81.9 & 5.6 & 5.6 & 4.2 & 2.8 & .974 \\
$\begin{array}{l}\text { Internet } \\
\text { Traditional knowledge }\end{array}$ & 97.2 & 1.4 & 0.0 & 0.0 & 1.4 & .484 \\
$\begin{array}{l}\text { Extension officers } \\
\text { Field days }\end{array}$ & 70.0 & 2.8 & 1.4 & 8.3 & 87.5 & .597 \\
& 75.0 & 9.7 & 8.3 & 5.6 & 5.6 & 1.189 \\
\hline
\end{tabular}

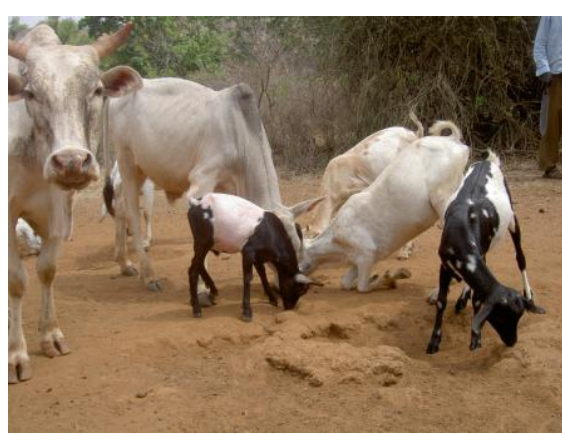

Figure 1. cattle and goats consuming natural lick at Kibuuri site in Kamwimbi Sublocation Igambang'ombe

\subsection{Farmers knowledge on natural licks}

\subsubsection{Local names of the natural lick}

Division

There are different local names used by farmers to refer to the natural lick and these names includes: Mwonyo, King'enyo, Mwunyu and Munge'nyo. However, majority (67\%) of the farmers call the natural lick, Mwonyo (Fig. 2) as it is locally called Siella in Northern Ghana[17].

The use of different names is associated with various ethnic groups in the area namely: Chuka, Mbeere, Tharaka, Muthambi and Mwimbi. The term Mwonyo is mainly used by the original inhabitants who forms the majority and it is the common name used in the study area.

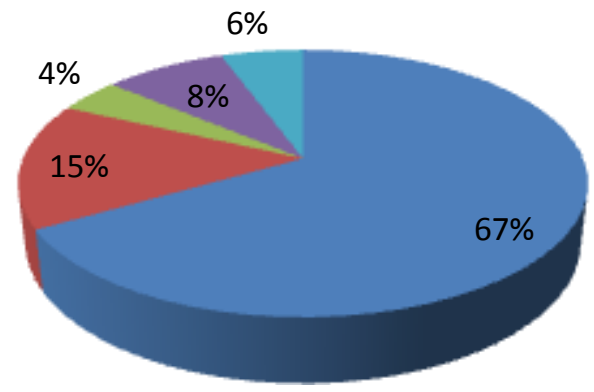

Mwonyo King'enyo Mwunyu Mwonyo \& King,enyo Mung'enyo

Figure 2: local names of the natural lick 


\subsubsection{Methods used to distinguish natural licks}

This study used a 5-point measurement scale, 1 (Strongly disagree), 2 (Disagree), 3 (Neither agrees nor disagrees), 4 (Agree) and 5 (Strongly agree) to establish how farmers distinguished natural licks. As shown in Fig. 3 below, majority of the farmers strongly agreed that natural lick is distinguished from normal soil by following animal's trend (85\%), tasting the soil (71\%) and the color of the soil (64\%). This shows that animals helped farmers in detecting the sites wth the licks and also farmers regarded natural licks as useful resourse to the animals by using their tongue to taste. The use of the tongue by farmers for tasting shows the degree of ignorance about the risks involved such as cotracting diseases, parasites and toxic elements found in the soil.

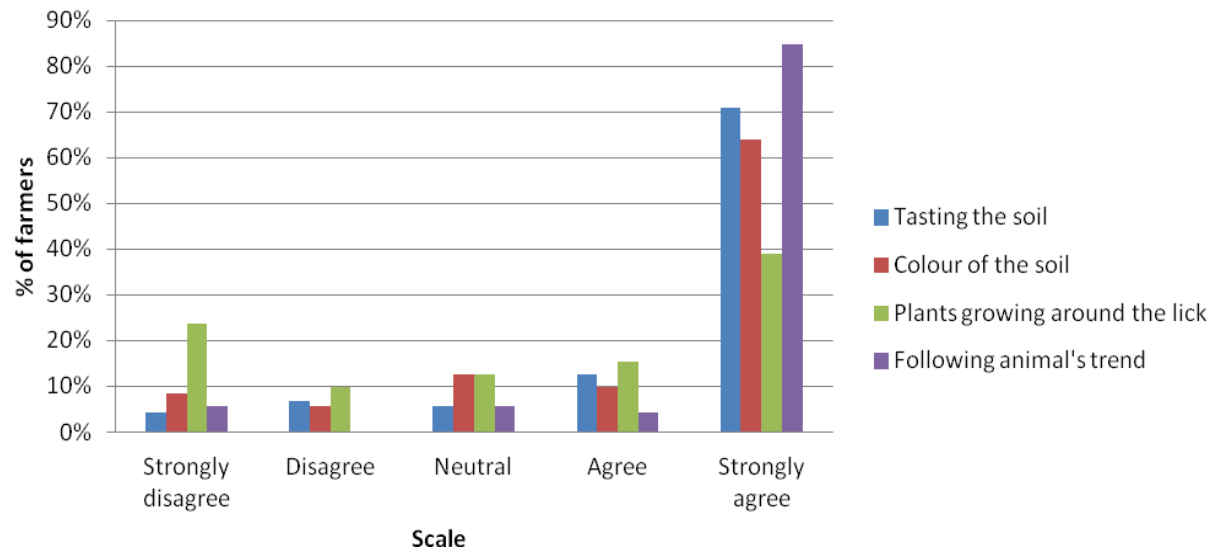

Figure 3. methods used to distinguish natural licks

\subsection{Famers perception on availability usage and benefits of natural licks}

This study used a 5-point measurement scale, 1 (Strongly disagree), 2 (Disagree), 3 (Neither agrees nor disagrees), 4 (Agree) and 5 (Strongly agree) to establish the farmers perceptions on availability, usage and perceived benefits of natural licks. The data revealed that majority $(63.9 \%)$ of the farmers strongly agreed that natural licks are readily available for the livestock (Table 4). This was favoured by the presence of licks in many parts of the study area and minimal cost of obtaining the lick. However, 59.7\% of the farmers strongly agreed that the natural lick was available but not accessible to all the farmers. This can be attributed to the emergence of private land ownership in some areas and reduction of communal grazing due to population pressure. Some farmers lived far from the natural licks which contributed to poor accessibility.

It was established that majority of farmers (48.6\%) strongly agreed that most farmers use natural lick always and $36.1 \%$ used occasionaly. This showed that natural lick is being used in the study area for the benefits of the animals which supports the work done by Montenegro[18] who concluded that, the existence of natural licks in an area could reduce the costs of obtaining sufficient nutrition and maintaining animal health.

As shown in Table 4, most farmers agreed that natural licks improve digestion (77.8\%), provide essential minerals to animals (81.9\%), increases milk production $(56.9 \%)$ and that they have medicinal value (48.6\%) to animals. It was observed that some farmers made blocks from the natural licks and gave to animals (Fig. 4) when they started feeding on papers and clothes on assumption that this abormal behaviour can be corrected by use of natural licks. The values of standard deviation in Table 4 ( 0.316 to 1.635$)$ demonstrates that perceptions on availability, usage and benefits of natural licks does not vary so much hence the farmers opinions were the same.

Table 4: Framers perception on availability usage and benefits of natural licks ( $\mathrm{n}=72)$

\begin{tabular}{lllllll}
\hline Variables & $\begin{array}{l}\text { Strongly } \\
\text { disagree } \\
(\%)\end{array}$ & $\begin{array}{l}\text { Disagree } \\
(\%)\end{array}$ & $\begin{array}{l}\text { Neutral } \\
(\%)\end{array}$ & $\begin{array}{l}\text { Agree } \\
(\%)\end{array}$ & $\begin{array}{l}\text { Strongly } \\
\text { agree } \\
(\%)\end{array}$ & $\begin{array}{l}\text { Standard } \\
\text { deviation }\end{array}$ \\
\hline $\begin{array}{l}\text { Availability of natural licks } \\
\text { Natural licks are always available for the animals }\end{array}$ & 12.5 & 9.7 & 2.8 & 11.1 & 63.9 & 1.486 \\
$\begin{array}{l}\text { Natural licks are available in some periods of the year } \\
\text { Natural licks are available but not accessible to all }\end{array}$ & 55.6 & 16.7 & 2.8 & 9.7 & 15.3 & 1.538 \\
farmers & & 4.2 & 1.4 & 13.9 & 59.7 & 1.635 \\
Natural licks are never available for the animals & 86.1 & 11.1 & 1.4 & 0.0 & 1.4 & .597 \\
Usage of natural licks & & & & & & \\
Most farmers use natural licks always & 13.9 & 16.7 & 8.3 & 12.5 & 48.6 & 1.549 \\
Farmers use natural licks occasionally & 12.5 & 13.9 & 6.9 & 30.6 & 36.1 & 1.417 \\
Farmers rarely use natural licks & 23.6 & 40.3 & 12.5 & 15.3 & 8.3 & 1.243 \\
Farmers do not use natural licks for their animals & 84.7 & 13.9 & 1.4 & 0.0 & 0.0 & .411 \\
\hline
\end{tabular}


Livestock farmers perceptions on the relevance of natural licks in Igambang'ombe Division, ....

\begin{tabular}{|c|c|c|c|c|c|c|}
\hline \multicolumn{7}{|l|}{ Perceived benefits } \\
\hline Natural licks improve digestion & 2.8 & 1.4 & 9.7 & 8.3 & 77.8 & .932 \\
\hline Natural licks provide essential minerals & 1.4 & 0.0 & 2.8 & 13.9 & 81.9 & .645 \\
\hline Natural licks increase milk production & 1.4 & 4.2 & 20.8 & 16.7 & 56.9 & 1.014 \\
\hline Natural licks have medicinal value & 6.9 & 2.8 & 19.4 & 22.2 & 48.6 & 1.198 \\
\hline Natural licks are not beneficial to the animals & 88.9 & 11.1 & 0.0 & 0.0 & 0.0 & .316 \\
\hline
\end{tabular}

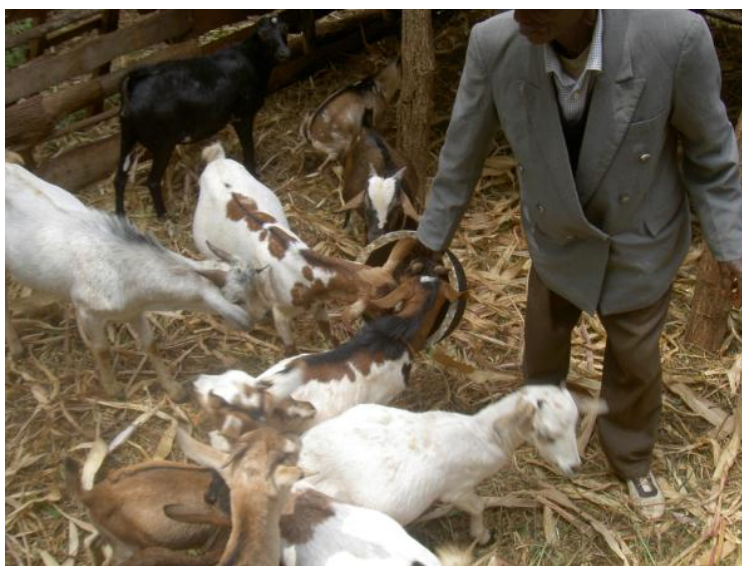

Figue 4. livestock farmer offering home made natural lick block to his goats in Igamatundu Sublocation Igambang'ombe Division

\subsection{Natural licks trade in Igambang'ombe Division}

Results in table 5 revealed that, $63.9 \%$ of the respondents reported that, natural lick was normally sold to earn income. This shows that natural lick is beneficial to farmers in that, apart from using the lick for their animals they can also trade with it. This promotes diversification of the farmers income and also reduces poverty.

Apart from cash, natural lick is used in barter trade (29\%) with human foodstuffs like cereals and bananas mostly during the times of hunger. The reason was that most of the areas where natural licks are found are marginal and crop production was poor. This table further shows that $52.8 \%$ of respondents indicated that anybody willing to harvest natural licks can trade with it. This high percentage might be due to the fact that most of the land is not adjudicated and the value of natural lick might not be well understood by the occupants of the land.

Most of the farmers who are involved in the trade of natural licks use containers for measuring $(59.7 \%)$ and sell at approximately Kenya shillings 40 (40.1\%) for a 2 kilogram container.

Table 5. Trade on natural lick in Igambang'ombe $(n=72)$

\begin{tabular}{lrc}
\hline Variables & $\begin{array}{c}\text { Yes } \\
(\%)\end{array}$ & $\begin{array}{l}\text { No } \\
(\%)\end{array}$ \\
\hline Is natural lick sold to ern income? & 63.9 & 36.1 \\
Who sells natural lick? & 2.8 & 97.2 \\
The owner of the land where natural lick is found & 11.1 & 88.9 \\
Local goverment officials & 52.8 & 47.2 \\
Anybody willing to harvest & & \\
Which form is the natural lick sold? & 1.4 & 98.6 \\
Packaged in small quantities & 4.2 & 98.5 \\
Measured in kiograms & 59.7 & 40.3 \\
Measured in containers & 1.4 & 98.6 \\
No standard measure & & \\
Price of 2 Kg container of natural ick (KES) & 11.3 & 88.7 \\
20 & 5.7 & 94.3 \\
30 & 40.1 & 59.9 \\
40 & 28.3 & 71.7 \\
50 & 13.2 & 86.8 \\
100 & 39.6 & 60.4 \\
\hline
\end{tabular}

\subsection{Analysis of variance}

Analysis of variance was performed to find out whether gender and level of education influenced the perception of farmers towards natural licks. An assessment of assumptions of normality and homogeneity of variance showed no major violations of assumptions in the two tests. 
Results in Table 6 on one-way ANOVA between gender showed that there was no statistically significant difference in perceptions between men and women, $F(1,70)=0.222$, p >0.05. Similarly, A one-way ANOVA between different education levels (Table7) showed that there was no statistically significant difference in perceptions between educated and uneducated farmers in the region, $\mathrm{F}(4,67)=0.787, \mathrm{p}>0.05$.

Table 6: Analysis of variance on ender

\begin{tabular}{lccccc}
\hline & Sum of Squares & $\mathrm{df}$ & Mean Square & $\mathrm{F}$ & Sig. \\
Between Groups & .053 & 1 & .053 & .222 & .639 \\
Within Groups & 16.824 & 70 & .240 & & \\
Total & 16.878 & 71 & & & \\
\hline
\end{tabular}

Table 7: Analysis of variance on ducation level

\begin{tabular}{lccccc}
\hline & Sum of Squares & df & Mean Square & F & Sig. \\
Between Groups & .757 & 4 & .189 & .787 & .538 \\
Within Groups & 16.120 & 67 & .241 & & \\
Total & 16.878 & 71 & & & \\
\hline
\end{tabular}

\section{Conclusion}

Most of the farmers believed that natural licks improves digestion, provides essential minerals, increases milk production and have medicinal value. This shows a positive perception of the farmers towards natural licks. Farmers perceptions originated from the knowledge on traditional practices. However, there is need for the promotion of adoption of the natural lick value to the animals through; chemical characterization on the licks, demarcation and preservation of the natural lick sites as public utility, marketing startegies, and to create awareness on how to incorporate natural licks in animal ration.

\section{Acnowledgement}

The authors would wish to thank Chuka University management for financial and institutional support.

\section{References}

[1] Council of the European Union, Press release, 3241st council meeting, foreign affairs (Brussels, 27.-28. ,2013)

[2] X. Diao, P. Hazell, D. Resnick and J. Thurlow The role of agriculture in development: implications for Sub-Saharan Africa (International Food Policy Research Institute 2033 K Street, NW Washington, D.C. 20006-1002, U.S.A., 2007)

[3] A. Challinor, T. Wheeler, Garforth, P. Craufurd, and A. Kassam, Assessing the vulnerability of food crop systems in Africa to climate change. Climatic Change, 83 (3). 2007, 381-399

[4] Kenya vision 2030: The popular version, Government of Kenya, 2007, 13

[5] J. K. Kiptarus, Focus on livestock sector: Supply policy framework strategies status and links with value addition, Presented at the workshop on value asses food \& export investment, Grand regency hotel, Nairobi, 2005

[6] Ministry of Livestock Development, Session paper no 2 of 2008 on National Livestock Policy, Government of Kenya, 2008

[7] P. K. Thornton, Livestock production: recent trends, future prospects. Philosophical Transactions of the Royal Society B 365, 2010, 2853-2867

[8] E. M. Aregheore, D. Hunter, D. Perera, and M. T. Mautoatasi, The soil-plant phenomena. Serum mineral status of Fuji fantastic sheep grazing Batiki grass (IschaemumaristatumVar.indicum) and Pangola grass (Digitariadecumbens) in Samoa., Journal of Animal and Veterinary Advances 6(3), 2007, 349-357.

[9] U. G. Limpitlaw, Ingestion of Earth materials for health by humans and animals, International Geology Review, 52:7-8, 2010, 726744

[10] A. Link, N.Galvis, E. Fleming and A. Di Fiore, Patterns of mineral lick visitation by spider monkeys and howler monkeys in Amazona. Are licks perceived as risky areas? American Journal of Primatology, 73, 2011,386-396.

[11] K. L. Parker and J. B. Ayote, Ecological Importance of Mineral Licks in the Tuchodi Watershed, North-Central British Columbia, Natural Rsources and Environmental Studies, Uuniversity of Northern British Columbia Prince George,British Columbia V2N 4Z9, 2004

[12] National Environment Management Authority (District Environment Action Plan (DEAP) 2006-2011, Meru South District, 2007)

[13] Statistical Package for social sciences Version17.0, SPSS Inc. 233 South Wacker Drive, 11th Floor Chicago, IL 60606-6412, 2008

[14] A. Khan, and M. Akram, Farmers' perception of extension methods used by Extension Personnel for dissemination of new agricultural technologies in Khyber Pakhtunkhwa, Pakistan. Sarhad J. Agric. 28(3), 2012, 511-520

[15] J. Garba, A.Y. Yari, M. Haruna, and S. Ibrahim, Traditional poultry production: The role of women in Kaura-Namoda local government area, Zamfara State, Nigeria. African Jounal of Agriculyural Research, 8(26), 2013, 3415-3421

[16] G. Ndeng'e, C. Opiyo, J. Mistiaen, and P. Kristjanson, Geographic Dimensions of Well-Being in Kenya: Where are the Poor? From Districts to Locations , Kenya. Ministry of Planning and National Development. Nairobi (Kenya): Central Bureau of Statistics, (1), 2003,164

[17] N. Karbo, Natural mineral licks to enhance livestock growth, Appropriate Technology,34(1), 2007, 46-48

[18] O. L. Montenegro, Natural licks as keystone resources for wildlife and people in Amazonia, doctoral diss., University of Florida PhD., 2004 